Egyptian

Orthodontic Journal

\title{
PHARYNGEAL AIRWAY CHANGES WITH SURGICAL ORTHODONTIC CORRECTION OF SKELETAL CLASS III CASES
}

\begin{abstract}
Zaher $A^{1}$, ALKenany $W^{2}$, Kandeela $B^{3}$
ABSTRACT:

Aim: To determine the changes in pharyngeal airway dimensionat three levels: naso, oro and hypopharyngeal, in Class III patients treated by maxillary advancement and mandibular setback surgery, and to find any possible correlation between surgical movements and the changes of the pharyngeal air way space. Methods: lateral cephalometric radiograph records of 15 subjects suffering of skeletal Class III deformities (8 females 7 males), theage wasranged from (18 to 24) years, were assessed atT0 (Initial before treatment), T1: (Before surgery), T2: (After surgery), T3: (Post-treatment). Results: The nasopharyngeal airway space showed increase from (T1 to $\mathcal{T} 2$ ) and from (T1to $\mathcal{T} 3$ ), while it showed decrease in the follow up period (T3 - T2). The hypopharyngeal airway space showed decrease from (T1 to T2) and from (T1 to T3), while it showed increase in the follow up period (T3 -T2). The oropharyngeal airway space showed no changes among all treatment stages. Conclusion: maxillary advancement and mandibular setback surgery caused an increase at the nasopharyngeal level and decreases at the hypopharyngeal levels respectively, while no change occurred at oropharyngeal. Strong correlation existed between surgical maxillary advancement and the increase of upper pharyngeal airway space, while no correlation was found between the surgical mandibular setback and the decrease of lower pharyngeal air way space in bimaxillary surgery.
\end{abstract}

1- Professor of Orthodontics, Faculty of Dentistry, Alexandria University

2- Professor of Orthodontics, Faculty of Dentistry, Alexandria University

3- Resident, Department of Orthodontics, Faculty of Dentistry, Alexandria University

Volume 44 - December 2013 
Egyptian

Orthodontic Journal

\section{INTRODUCTION}

Skeletal Class III malocclusion is a structural deviation in the sagittal relationships of the maxillary and mandibular bony arches. The treatments of choice are based on extent of the deformity, degree of desirable jaw movement, and anticipated soft tissue changes following surgical intervention. ${ }^{(1)}$ The function of the upper airway is highly influenced by its anatomical structure. The pharynx is voluntarily dilated when the patient is awake, but this control is lost during sleep and the respiratory parameters may deteriorate due to the abnormal anatomical structure of the upper airways..$^{(2,3)}$ The anatomical and aesthetic aspects of orthognathic surgery are important, but the importance of functional consequences might overcome these aspects. Efforts to improve occlusion and facial aesthetics, and consequently the patient's quality of life, may have the opposite effect on functional structure.

Many studies ${ }^{(4-9)}$ reported reduction in the dimensions of the retrolingual and hypopharyngeal airway after mandibular setback surgery. At the same time, Mao et al ${ }^{(10)}$ found that although there was some increase both in airway space width and area during the follow-up period, they did not increase to their original values. While others ${ }^{(11-13)}$ showed a maintenance of the decrease of the lower pharyngeal airway size, with long follow up, after mandibular setback surgery.

On the other hand some studies ${ }^{(14-19)}$ suggested that the changes in oropharyngeal complex are temporary as the tissues re-adapt, resulting in partial or total resolution. However, some studies ${ }^{(20,21)}$ of upper airway changes after bimaxillary surgery have reported significant reduction of the upper airway dimensions, while others ${ }^{(22-25)}$ have indicated that the decrease in the posterior airway space after bimaxillary procedures was less than with mandibular setback alone. This study was carried out to test the null hypothesis that bimaxillary osteotomies involving maxillary advancement and mandibular setback will not induce any changes inanteroposterior pharyngeal airway dimensions.

Volume 44 - December 2013 
Egyptian

Orthodontic Journal

\section{MATERIAL AND METHODS}

This observational retrospective study was carried out on lateral cephalometric radiograph records of 15 subjects (7 males and 8 females) age ranged from (18 to 24) years before starting the treatment. The patients were suffering of skeletal Class III deformities and were selected from a group of the orthognatic surgery treated with maxillary advancement and mandibular setback. Patients who met the following criteria were included in the study:

1- Skeletal class III cases showing a combination of maxillary deficiency and mandibular prognathism.

2- Surgical orthodontic treatment including maxillary advancement and mandibular setback.

3- No other additional relevant surgery was performed during the duration of the study.

4- No cleft of lip or palate or other syndrome existed.

5- The presence of complete record before and after surgery including lateral cephalometric radiograph.

6- Stable occlusion after end of treatment.

Lateral cephalometric radiographic records were collected at: T0: (Initial before treatment), T1: (before surgery), T2:(after surgery) and T3: (post-treatment) when the treatment was completed.

\section{Reliability of the landmark identification}

Ten lateral cephalograms were chosen randomly for landmark identification; each landmark was identified by an investigator and checked for location by another investigator. Accuracy of the measurement difference was compared to zero; the magnitude of the difference between the two measurements was not clinical significance.

\section{Intra-examinar reliability}

To minimize measurement error each cephalogram was traced and measured manually by the same investigator. All linear and angular measurements were repeated at another setting, and the mean value of the two measurements was used. 
The permissible difference was $0.5 \mathrm{~mm}$ for linear measurements or $1^{\circ}$ for angular measurements, if the difference between the two measurements was more than 0.5 or $1^{\circ} \mathrm{a}$ third measurement was taken and the mean of the nearest two measurements was used.

The pharyngeal airway space was determinedby measuring the following distance (figur1): the distance from pterygomaxillary fissure (Ptm) to upper pharyngeal wall (UPW) representing the nasopharyngeal airway space, the distance from tip of the soft palate (U)to middle pharyngeal wall (MPW) representing the oropharyngeal airway space, the distance from vellicula(V) to lower pharyngeal wall (LPW) representing the hypopharyngeal airway space, the minimal distance between the base of tongue and the posterior pharyngeal wall (PASmin) which represents the minimal pharyngeal airway space. ${ }^{(20,22,25,26)}$

A horizontal reference line (HRl) was drawn by rotating 7 degrees clockwise to the sella-nasion line at nasion and a vertical reference line (VRl) was drawn perpendicular to this line at nasion. ${ }^{(27-31)}$ The hard tissue landmarks were measured to the horizontal and vertical reference lines in the presurgical and postsurgical cephalograms. (figure2)

\section{Calculation of mandibular movements}

The anteroposterior mandibular movement was measured as a change in length of the line connecting the pogonion $(\mathrm{Pg})$, menton $(\mathrm{Me})$ and the $(\mathrm{B})$ point to the vertical reference line.

The vertical mandibular movement was measured as a change in length of the line connecting the pogonion $(\mathrm{Pg})$, menton $(\mathrm{Me})$ and the $(\mathrm{B})$ point to the horizontal reference line.

\section{Calculation of maxilla movements}

The anteroposterior movement of the maxilla was measured as a change in length of the line connecting the anterior nasal spine (ANS), posterior nasal spine (PNS) and the A point to the vertical reference line.

The vertical movement of the maxilla was measured as a change in length of the line connecting the anterior nasal spine (ANS), posterior nasal spine (PNS) and the A point to the horizontal reference line. 


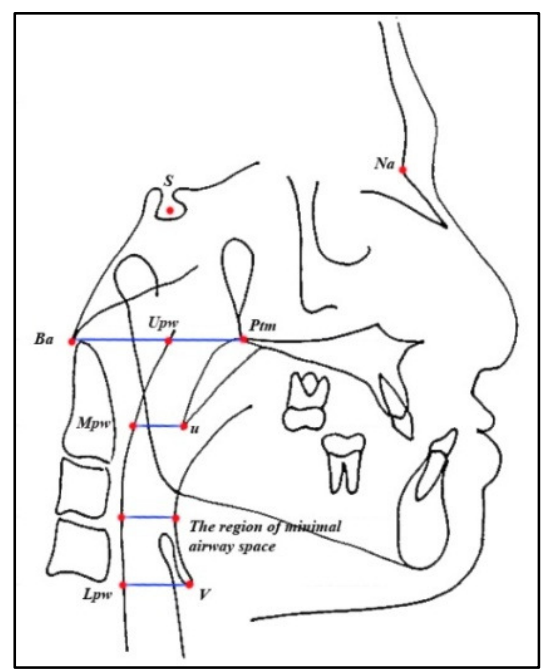

Figure 1:The following Pharyngeal airway linear measurements were used.

Ptm-UPW: The distance from ptm to UPW, representing the nasopharyngeal airway space. U-MPW: The distance from U to MPW, representing the oropharyngeal airway space. V-LPW: The distance from V to LPW, representing the hypopharyngeal airway space. PASmin: The minimal distance between the base of tongue and the posterior pharyngeal wall, which represents the minimal pharyngeal airway space

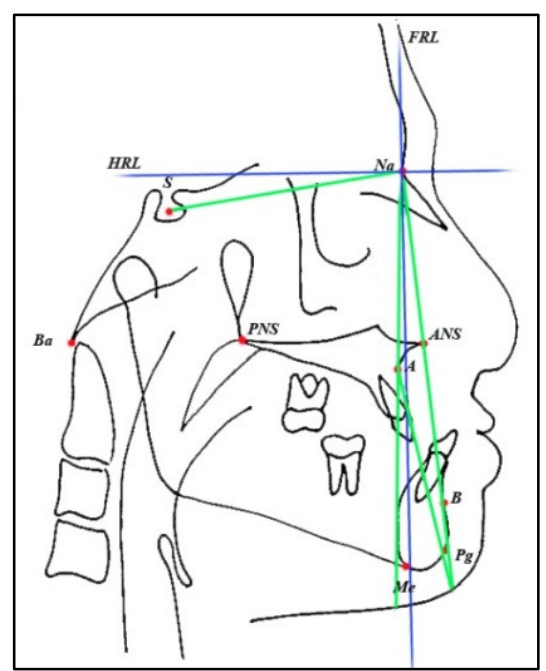

Figure2: Reference lines used in the study. HRL: The horizontal reference line was constructed by raising a line $7^{\circ}$ from the sella-nasion line at nasion.VRL: The vertical reference line was constructed perpendicular to the (HRL) at nasion. 
Egyptian

Orthodontic Journal

\section{RESULTS}

There was no difference observed when comparing all parameters from (T0) to (T1); hence only measurements at (T1) were used for comparison.

The pharyngeal airway space measurements at upper pharyngeal airway (Ptm-UPW)and lower pharyngeal airway (V-LPW and PAS min) showed the following changes. Table (I).

- The upper pharyngeal airway space (Ptm-UPW) at (T2) and(T3) was significantly wider compared with its initial width at (T1), while it did not change from (T2 to T3).

- The middle pharyngeal airway space (U-MPW) showed no changes among all treatment stages.

- The lower pharyngeal airway space (V-LPW and PAS min) at(T2) and(T3)were significantly narrower compared with their initial width at (T1). While it did not change from(T2 to T3).

Table (II) showed the comparisons of the mean changes from (T1 to T2), (T2 to T3), and (T1 to T3). In the surgical change (T2-T1) the (Ptm-UPW) showed a significant increase, while it showed significant decrease in the follow up period (T3 -T2), at the end of treatment the overall changes (T3-T1) showed no significant difference from surgical changes (T2-T1). There was no change in (U.MPW) in all treatment stages. In the surgical change (T2-T1) the (V.LPW) and (PAS min) showed a significant decrease, while it showed significant increase in the follow up period (T3 -T2), at the end of treatment the overall changes (T3-T1) showed no significant difference from surgical changes (T2-T1)

All parameters indicating anetroposterior maxillary position showed statistically significant differences from (T1 to T2) and from (T1to T3), while it showed no statistically significant differences from (T2 to T3). At ANS the final measurement indicating maxillary anterior position at (T3) was significantly larger comparedwith its initial position at (T1), while this parameter showed no significant change from (T2 to T3). Table (III) 
The results in table (IV) showed a significant increase in value indicating maxillary anterior position (T2-T1). The surgical forward movements for the maxilla measured at ANS showed significant decrease in the follow up period (T3-T2). At the end of treatment the overall changes (T3-T1) showed significant difference from surgical changes (T2-T1).

It was found that all parameters indicating anteroposterior mandibular position showed no statistically significant differences from (T2 toT3), while it showed statistically significant differences from (T1 to $\mathrm{T} 2$ ) and from (T1to T3). At B point the final measurement indicating mandibular posterior position at (T3) was significantly smaller compared with its initial position at (T1). While this measurement showed no significant change from (T2 to T3). Table (V)

The results in table (VI) showed a significant decrease in value indicating backward mandibular position at (T2-T1). The surgical movements for the mandible in backward position measured at $\mathrm{B}$ point showed significant increase in forward position in the follow up period (T3-T2). At the end of treatment the overall changes (T3-T1) showed significant difference from surgical changes (T2-T1).

Table (I): Comparisons of pharyngeal airway space horizontal liner measurements (mm) before treatment (T0), before surgery (T1), after surgery (T2) and post treatment (T3).

\begin{tabular}{|l|c|c|c|c|c|}
\hline & \multicolumn{4}{|c|}{ Mean (SD) } & \multirow{2}{*}{ P value } \\
\cline { 2 - 5 } & $\begin{array}{c}\text { Before treatment } \\
\text { (T0) }\end{array}$ & $\begin{array}{c}\text { Before surgery } \\
\text { (T1) }\end{array}$ & $\begin{array}{c}\text { After surgery } \\
\text { (T2) }\end{array}$ & $\begin{array}{c}\text { Post treatment } \\
\text { (T3) }\end{array}$ & \\
\hline Ptm-UPW & $21.06(3.76) \mathrm{a}$ & $21.06(3.75) \mathrm{a}$ & $25.59(3.39) \mathrm{b}$ & $24.05(3.57) \mathrm{b}$ & $<0.0001^{*}$ \\
\hline U-MPW & $13.90(3.99)$ & $13.96(4.06)$ & $14.91(4.42)$ & $14.28(3.73)$ & 0.12 \\
\hline V-LPW & $21.04(2.70) \mathrm{a}$ & $20.81(2.83) \mathrm{a}$ & $16.27(3.01) \mathrm{b}$ & $17.97(2.69) \mathrm{b}$ & $<0.0001^{*}$ \\
\hline PAS min & $14.09(3.37) \mathrm{a}$ & $14.11(3.44) \mathrm{a}$ & $10.48(2.87) \mathrm{b}$ & $11.49(2.67) \mathrm{b}$ & $<0.0001^{*}$ \\
\hline
\end{tabular}

*: Statistically significant at $\mathrm{p} \leq 0.05$ 
Table (II): Comparisons of the mean changes in pharyngeal airway space horizontal linear measurements $(\mathrm{mm})$ with various treatment stages.

\begin{tabular}{|l|c|c|c|c|}
\hline & \multicolumn{4}{|c|}{ Mean (SD) } \\
\cline { 2 - 5 } & $\begin{array}{c}\text { Surgical change } \\
\text { (T2- T1) }\end{array}$ & $\begin{array}{c}\text { Post- surgical change } \\
\text { (T3-T2) }\end{array}$ & $\begin{array}{c}\text { Overall change } \\
\text { (T3-T1) }\end{array}$ & P value \\
\hline Ptm-UPW & $4.53(1.47) \mathrm{a}$ & $-1.54(0.91) \mathrm{b}$ & $2.99(1.25) \mathrm{a}$ & $<0.0001^{*}$ \\
\hline U-MPW & $0.94(2.22)$ & $-0.62(1.35)$ & $0.32(1.35)$ & 0.37 \\
\hline V-LPW & $-4.54(1.59) \mathrm{a}$ & $1.70(1.29) \mathrm{b}$ & $-2.84(1.24) \mathrm{a}$ & $<0.0001^{*}$ \\
\hline PAS min & $-3.63(1.72) \mathrm{a}$ & $1.01(0.97) \mathrm{b}$ & $-2.62(1.11) \mathrm{a}$ & $<0.0001^{*}$ \\
\hline
\end{tabular}

*: Statistically significant at $\mathrm{p} \leq 0.05$

Table (III): Comparisons of the parameter indicating anteroposterior maxillary position: before treatment (T0), before surgery (T1), after surgery (T2) and post treatment (T3).

\begin{tabular}{|l|c|c|c|c|c|}
\hline & \multicolumn{4}{|c|}{ Mean (SD) } & \multirow{2}{*}{ P value } \\
\cline { 2 - 5 } & $\begin{array}{c}\text { Before } \\
\text { treatment (T0) }\end{array}$ & $\begin{array}{c}\text { Before } \\
\text { surgery(TI) }\end{array}$ & $\begin{array}{c}\text { Aftersurgery } \\
\text { (T2) }\end{array}$ & $\begin{array}{c}\text { Posttreatment } \\
\text { (T3) }\end{array}$ & \\
\hline ANS-VRL & $1.86(3.50) \mathrm{a}$ & $1.91(3.49) \mathrm{a}$ & $6.11(3.16) \mathrm{b}$ & $4.70(3.15) \mathrm{b}$ & $<0.0001^{*}$ \\
\hline PNS-VRL & $-46.65(4.84) \mathrm{a}$ & $-46.59(4.96) \mathrm{a}$ & $-42.29(4.44) \mathrm{b}$ & $-43.74(4.75) \mathrm{b}$ & $<0.0001^{*}$ \\
\hline A-VRL & $-1.78(4.90) \mathrm{a}$ & $-1.66(4.66) \mathrm{a}$ & $2.64(4.46) \mathrm{b}$ & $1.45(4.72) \mathrm{b}$ & $<0.0001^{*}$ \\
\hline
\end{tabular}

Negative values indicate posterior position to vertical reference line.*: Statistically significant at $\mathrm{p} \leq 0.05$

Table (IV): Comparisons of the mean anteroposteiormaxillary position changes between various treatment stages.

\begin{tabular}{|l|c|c|c|c|}
\hline & \multicolumn{4}{|c|}{ Mean (SD) } \\
\cline { 2 - 5 } & $\begin{array}{c}\text { Surgical change } \\
\text { (T2- T1) }\end{array}$ & $\begin{array}{c}\text { post- surgical change } \\
\text { (T3-T2) }\end{array}$ & $\begin{array}{c}\text { Overall change } \\
\text { (T3-T1) }\end{array}$ & P value \\
\hline ANS-VRL & $4.20(1.58) \mathrm{a}$ & $-1.41(0.94) \mathrm{b}$ & $2.79(1.69) \mathrm{c}$ & $0.000^{*}$ \\
\hline PNS-VRL & $4.30(1.49) \mathrm{a}$ & $-1.45(1.03) \mathrm{b}$ & $2.85(1.06) \mathrm{c}$ & $0.000^{*}$ \\
\hline A-VRL & $4.31(1.14) \mathrm{a}$ & $-1.19(0.86) \mathrm{b}$ & $3.12(1.24) \mathrm{c}$ & $0.000^{*}$ \\
\hline SNA & $5.33(1.80) \mathrm{a}$ & $-1.23(0.94) \mathrm{b}$ & $4.10(2.09) \mathrm{c}$ & $0.000^{*}$ \\
\hline
\end{tabular}

*: Statistically significant at $\mathrm{p} \leq 0.05$. 
Table (V): Comparisons of the parameters indicating anteroposterior mandibular position: before treatment (T0), before surgery (T1), after surgery (T2) and post treatment (T3).

\begin{tabular}{|l|c|c|c|c|c|}
\hline & \multicolumn{4}{|c|}{ Mean (SD) } & \multirow{2}{*}{ P value } \\
\cline { 2 - 5 } & $\begin{array}{c}\text { Before } \\
\text { treatment (T0) }\end{array}$ & $\begin{array}{c}\text { Before surgery } \\
\text { (T1) }\end{array}$ & $\begin{array}{c}\text { Aftersurgery } \\
\text { (T2) }\end{array}$ & $\begin{array}{c}\text { Post treatment } \\
\text { (T3) }\end{array}$ & \\
\hline B-VRL & $5.60(6.17) \mathrm{a}$ & $5.54(6.21) \mathrm{a}$ & $-0.30(5.45) \mathrm{b}$ & $1.06(5.69) \mathrm{b}$ & $<0.0001^{*}$ \\
\hline Pg-VRL & $5.40(7.15) \mathrm{a}$ & $5.31(7.27) \mathrm{a}$ & $-0.53(6.73) \mathrm{b}$ & $0.75(6.77) \mathrm{b}$ & $<0.0001^{*}$ \\
\hline Me-VRL & $-1.28(7.58) \mathrm{a}$ & $-1.45(7.67) \mathrm{a}$ & $-6.97(7.48) \mathrm{b}$ & $-5.82(7.49) \mathrm{b}$ & $<0.0001^{*}$ \\
\hline
\end{tabular}

Negative values indicate posterior position to vertical reference line.

*:Statistically significant at $\mathrm{p} \leq 0.05$

Table (VI): Comparisons of the mean anteroposteior mandibular position changes between various treatment stages.

\begin{tabular}{|l|c|c|c|c|}
\hline & \multicolumn{4}{|c|}{ Mean (SD) } \\
\cline { 2 - 5 } & $\begin{array}{c}\text { Surgical change } \\
\text { (T2- T1) }\end{array}$ & $\begin{array}{c}\text { Post-surgical change } \\
\text { (T3-T2) }\end{array}$ & $\begin{array}{c}\text { Overall change } \\
\text { (T3-T1) }\end{array}$ & P value \\
\hline B-VRL & $-5.84(1.97) \mathrm{a}$ & $1.36(0.80) \mathrm{b}$ & $-4.48(1.98) \mathrm{c}$ & $<0.000^{*}$ \\
\hline Pg-VRL & $-5.84(2.32) \mathrm{a}$ & $1.28(1.04) \mathrm{b}$ & $-4.56(2.13) \mathrm{c}$ & $<0.000^{*}$ \\
\hline Me-VRL & $-5.52(1.54) \mathrm{a}$ & $1.14(0.60) \mathrm{b}$ & $-4.38(1.32) \mathrm{c}$ & $<0.000^{*}$ \\
\hline SNB & $-4.33(1.23) \mathrm{a}$ & $0.73(0.59) \mathrm{b}$ & $-3.60(1.30) \mathrm{c}$ & $<0.000^{*}$ \\
\hline NA-Pg & $17.20(5.12) \mathrm{a}$ & $-3.53(2.07) \mathrm{b}$ & $13.67(4.95) \mathrm{c}$ & $<0.000^{*}$ \\
\hline
\end{tabular}

*: Statistically significant at $\mathrm{p} \leq 0.05$

\section{DISCUSSION}

Airway changes were evaluated in this study by analyzing pre and postsurgical lateral cephalograms. Although the cephalogram only provides a two dimensional image of the pharyngeal airway, it has been used extensively in the assessment of sleep apnea and craniofacial form. ${ }^{(22,32)}$ Furthermore, Kawamata $\mathrm{A}$, et $\mathrm{al}^{(33)}$ showed a correlation between airway dimensions measured on lateral cephalograms and on three-dimensional computed tomograms. 
In the present study changes of the pharyngeal airway space dimension, as well as the amount of bimaxillary movement measured at various treatment stages were assessed and correlated with each other.

Obstruction of the upper airway has been reported to occur at various levels: nasopharynx, oropharynx, and hypopharynx. Similar to previous studies, ${ }^{(20,22,26)}$ (Ptm-UPW), (U-MPW), and (V-LPW, PASmin) were selected to represent the pharyngeal airway dimensions at the levels of nasopharynx, oropharynx, and hypopharynx, respectively.

Based on the findings, no maxillary vertical change was observed at all treatment stages; indicating that no maxillary impaction resulted from the surgery.

As the maxilla was moved forward during the operation, the upper pharyngeal airway space increased. It seems that the increase was as a result of advancement of the velum and velopharyngeal muscle with surgical maxillary advancement. ${ }^{(34)}$ Cakarne, Urtane and Skagers ${ }^{(26)}$ as well as other studies $^{(6,20,22,35-38)}$ found increase in nasopharyngeal airway space after bimaxillary surgery included maxillary advancement.

The increase of upper airway space was correlated to surgical advancement of the maxilla. This is in accordance with previous study by Hasebe et $\mathrm{al}^{(39)}$ who observed correlations between the amounts of maxillary anterior movement and changes in upper airway space. While changes in the upper airway spacewas not correlated with surgical setback of the mandible. It seems logical that the increase that happened in the upper air way dimension was not influenced much by the surgical mandibular setback.

Many studies ${ }^{(22,26,35)}$ have assessed time dependent pharyngeal airway changes after orthognathic surgery. In this study there was no correlation between changes in upper airway space and skeletal changes in the (10-12) months follow-up period. This suggests that the soft tissue does not follow the skeletal changes, and might have different manner of post-surgical adaptation with its supporting hard tissues.

Although the maxilla in our study was brought forward and the mandible backward, we did not observe any changes in the oropharyngeal space among all treatment stages. It seems that; the maxillary 
Egyptian

Orthodontic Journal

advancement dose not gained increase in the retropalataldimension when coupled with the mandibular setback, or that the bimaxillary operations reduce the negative effect of mandibular set back on the oropharynx with the advancement of the maxilla.

However the lower pharyngeal airway space was decreased after bimaxillary surgery, this was in agreement with previous studies ${ }^{(5,7,13,14,33)}$ of mandibular setback surgery alone. Our results were contradicted with findings of Jakobsone et al. ${ }^{(19)}$ They reported that after bimaxillary surgery with maxillary advancement and mandibular setback, oropharyngeal and hypo pharyngeal airway volume increased. They attributed that to the movement of the tongue to the space created by advancement of maxilla.

Despite immediate postoperative decrease in lower pharyngeal airway width in the present study, there was no correlation between the amount of mandibular setback and the lower pharyngeal air way narrowing. However, skeletal mandibular changes may be described by the reduction in the sagittal dimension only, whereas the base of tongue, hyoid bone, velum and pharyngeal walls are intimately related by their muscular and ligamentous attachments. It is likely that the morphology of these structures is influenced and compromised after surgical procedures. ${ }^{(13)}$ This finding agrees with other studies $^{(10,12)}$ who found no correlation between the amount of mandibular setback and airway space changes. While others ${ }^{(4,8)}$ emphasized that the reduction in pharyngeal air space area was correlated with the amount of mandibular setback.

Our finding showed an increase in the lower pharyngeal air way in the follow up period, but at the end of treatment it was still smaller than initial value. This might mean that the lower pharyngeal airway space continues to increase after surgery.

Despite a certain relapse tendency at the follow-up period indicated by the skeletal parameters such as SNB, no correlation was found between the lower airway space width changes and mandibular relapse. This might be attributed to compensatory functional readjustments of the hyoid, lingual, and cervical musculature to maintain airway patency in surgically altered 
environment. This was confirmed by Lee et $\mathrm{al}^{(40)}$ and Mao et $\mathrm{al}^{(10)}$ who found that there was no correlation between mandibular relapse and the amount of airway space changes.

Based on available information our results were inconsistent with findings of these other studies ${ }^{(19,20,26,36)}$ of bimaxillary surgery, our finding showed that maxillary advancement surgery combined with mandibular setback may be followed by decrease in lower pharyngeal airway at the levels of base of tongue and vallecula, an increase of pharyngeal airway at the level of the posterior nasal spine while at the level of soft palate remain unchanged.

Most researchers ${ }^{(41-43)}$ agreed that obstruction can be observed at any level of upper airway. However, the obstruction was often recorded at the oropharyngeal level $;^{(42,43)}$ it may even be associated with widening of the hypopharynx. ${ }^{(44)} \mathrm{A}$ systematic review of literature by Rama et $\mathrm{al}^{(45)}$ revealed that the oropharynx level might be the most compromise level.

The null hypothesis was not proven. The results of the present study showed that there was a widening of the upper airway and narrowing of the lower airway concomitant with maxillary advancement and mandibular setback surgery, whereas the middle airway did not show a change.

\section{CONCLUSIONS}

- Maxillary advancement and mandibular setback surgery in skeletal Class III patients caused an increase at the nasopharyngeal level and decreases at the hypopharyngeal levels, while no change was observed at the level of oropharyngeal.

- The maxillary advancement to some extent might compensate for the effect of mandibular setback at the oropharyngeal level.

- Changes in the upper pharyngeal airway space were correlated with the amounts of surgical maxillary advancement, whereas, changes in the lower pharyngeal airway space were not correlated with the amounts of surgical mandibular setback. 
Egyptian

Orthodontic Journal

\section{REFERENCES}

1- Gjörup H, Athanasiou A E. Soft-tissue and dentoskeletal profile changes associated with mandibular setback osteotomy. Am J OrthodDentofacialOrthop. 1991;100:312 23.

2- Akita S, Anraku K, Tanaka K, Yano H, Hirano A. Sleep disturbances detected by a sleep apnea monitor in craniofacial surgical patients. J Craniofac Surg. 2006; 17:44-9.

3- Goodday RHB, Precious DS, Morrison AD, Robertson CD. Obstructive sleep apnea syndrome: diagnosis and management. J Can Dent Assoc. 2001;67:652-8.

4- Tselnik M, Pogrel MA. Assessment of the pharyngeal airway space after mandibular setback surgery. J Oral Maxillofac Surg. 2000; 58:282-5.

5- Riley RW, Powell NB, Guilleminault C, Ware W. Obstructive sleep apnea syndrome following surgery for mandibular prognathism. J Oral MaxillofacSurg. 1987;45:450-2.

6- Turnbull NR, Battagel JM. The effects of orthognathic surgery on pharyngeal airway dimensions and quality of sleep. J Orthod. 2000;27:235-47.

7- Enacar A, Aksoy AU, Sencift Y, Haydar B, Aras K. Changes in hypopharyngeal airway space and in tongue and hyoid bone positions following the surgical correction of mandibular prognathism. Int J Adult OrthodOrthognath Surg. 1994;9:285-90.

8- Hochban W, Schurmann R, Brandenburg U, Conradt R. Mandibular setback for surgical correction of mandibular hyperplasia-does it provoke sleep-related breathing disorders? Int J Oral Maxillofac Surg. 1996;25:333-8.

9- Kawakami M, Yamamoto K, Fujimoto M, Ohgi K, Inoue M, Kirita $\mathrm{T}$. Changes in tongue and hyoid positions, and posterior airway space following mandibular setback surgery. J Craniomaxillofac Surg. 2005;33:24-7. 
10- Mao C, Aruga S, Matsuura M, Seto K. Changes in airway space following mandibular setback using sagittal split osteotomy and rigid internal fixation. Chin Med Sci J. 1997;12(2):96-101.

11- Greco JM, Frohberg U, Van Sickels JE. Long-term airway space changes after mandibular setback using bilateral sagittal split osteotomy. Int J Oral Maxillofac Surg. 1990;19(2):103-5.

12- Paoli JR, Lauwers F, Cances V, Tiberge M, Lacassagne L, Fossat W, et al. Upper airway changes after mandibular setback osteotomy. Concerns for obstructive sleep apnea. Rev StomatolChirMaxillofac. 2000;101(3):129-34.

13- Eggensperger N, Smolka W, lizuka T: Long-term changes of hyoid bone position and pharngeal airway size following mandibular setback by sagittal split ramus osteotomy. J Craniomaxillofac Surg. 2005;33: 111-7.

14- Athanasiou AE, Toutountzakis N, Mavreas D, Ritzau M, Wenzel A. Alterations of hyoid bone position and pharyngeal depth and their relationship after surgical correction of mandibular prognathism. Am J OrthodDentofacialOrthop. 1991;100:259-65.

15- Athanasiou AE. Morphologic and functional implications of the surgical-orthodontic management of mandibular prognathism: A comprehensive review. Am J OrthodDentofacialOrthop. 1993;103:439-47.

16- Nakagawa F, Ono T, Ishikawa Y, Kuroda T: Morphologicchanges in the upper airway structur e following surgical correction of mandibular prognathism. Int J Adult OrthodOrthognath Surg. 1998; 13:299-306.

17- Saitoh K. Long-term changes in pharyngeal airway morphology after mandibular setback surgery. Am J OrthodDentofacialOrthop 2004;125:556-61.

18- Marsan G, Cura N, Emekli U. Changes in pharyngeal(airway) morphology in Class III Turkish female patients after mandibular setback surgery. J Craniomaxillofac Surg. 2008;36:341-5. 
Egyptian

Orthodontic Journal

19- Jakobsone G,Neimane L, Krumina G.Two- and three-dimensional evaluation of the upper airway after bimaxillary correction of Class III malocclusion. Oral Surg Oral Med Oral Pathol Oral RadiolEndod. 2010;110:234-42.

20- Samman N, Tang SS, Xia J. Cephalometric study of the upper airway in surgically corrected class III skeletal deformity. Int $\mathrm{J}$ Adult OrthodOrthognath Surg. 2002;17:180-90.

21-Hwang S, Chung CJ, Choi YJ, Huh JK, Kim KH. Changes of hyoid, tongue and pharyngeal airway after mandibular setback surgery by intraoral vertical ramus osteotomy. Angle Othod. 2010;80:302-8.

22-Chen F, Terada K, Hua Y, Saito I. Effects of bimaxillary surgery and mandibular setback surgery on pharyngeal airway measurements in patients with Class III skeletal deformities. Am J OrthodDentofacialOrthop. 2007;131:372-7.

23-Degerliyurt K, Ueki K, Hashiba Y, Marukawa K, Nakagawa K,Yamamoto E. A comparative CT evaluation of pharyngeal airway changes in class III patients receiving bimaxillary surgery or mandibular setback surgery. Oral Surg Oral Med Oral Pathol Oral RadiolEndod. 2008;105:495-502.

24- Hong JS, Park YH, Kim YJ, Hong SM, Oh KM. Three-Dimensional Changes in Pharyngeal Airway in Skeletal Class III Patients Undergoing Orthognathic Surgery. J Oral Maxillofac Surg. 2011; 69(11):401-8.

25- Liukkonen M, Vahatalo K, Peltomaki T, Tiekso J, Happonen RP. Effect of mandibular setback surgery on the posterior airway size. Int J Adult OrthodOrthognath Surg. 2002;17:41-6.

26- Cakarne D, Urtane I, Skagers A.Pharyngeal airway sagittal dimension in patients with class III skeletal dentofacial deformity before and after bimaxillary surgery. Stomatologija. 2003; 5:13-6.

27- Lin SS, Kerr WJS. Soft and hard tissue changes in Class III patients treated by bimaxillary surgery. Eur J Orthod. 1998;20:25-33. 
Egyptian

Orthodontic Journal

28- Lew KKK, Loh FC, Yeo JF, Loh SA. Evaluation of soft tissue profile following intraoral ramus osteotomy in Chinese adults with mandibular prognathism. Int $\mathrm{J}$ Adult OrthodOrthognath Surg. 1990;5:189-97.

29- Mansour S, Burstone C, Legan H. An evaluation of soft tissue changes resulting from LeFort I maxillary surgery. Am J Orthod. 1983;84:37-47.

30- Mankad B, Cisneros GJ, Freeman K, Eisig SB. Prediction accuracy of soft tissue profile in orthognathic surgery. Int $J$ Adult OrthodOrthognathSurg. 1999;14:19-26.

31- Legan HL, Burstone CJ. Soft tissue cephalometric analysis for orthognathic surgery. J Oral Surg. 1980;38:744-51.

32- Ozbek MM, Miyamoto K, Lowe AA, Fleetham JA. Natural head posture, upper airway morphology and obstructive sleep apnea severity in adults. Eur J Orthod. 1998; 20: 133-43.

33- Kawamata A, Fujishita M, Ariji Y, Ariji E. Three-dimensional computed tomographic evaluation of morphologic airway changes after mandibular setback osteotomy for prognathism. Oral Surg Oral Med Oral Pathol Oral RadiolEndod. 2000;89: 278287

34- Schendel SA, Oeschlaeger M, Wolford LM, Epker BN. Velopharyngeal anatomy and maxillary advancement. J Maxillofac Surg. 1979; 7: 116-24.

35- Marsan G, VasfiKuvat S, Oztas E, Cura N, Susal Z, EmekliU. Oropharyngeal airway changes following bimaxillary surgery in Class III female adults. J Craniomaxillofac Surg. 2009;37:69-73.

36- Jakobsone G, Stenvik A, Espeland L. The effect of maxillary advancement and impaction on the upper airway after bimaxillary surgery to correct Class III malocclusion. Am J OrthodDentofacialOrthop. 2011;139:369-76.

37- Pereira-Filho VA, Castro-Silva LM, de Moraes M, Gabrielli MF, Campos JA, Juergens P. Cephalometric Evaluation of Pharyngeal Airway Space Changes in Class III Patients Undergoing Orthognathic Surgery. J Oral Maxillofac Surg. 2011;69(11):409-15. 
Egyptian

Orthodontic Journal

38- Greco JM, Frohberg U, Sickels JEV. Cephalometric analysis of longterm airway space changes with maxillary osteotomies. Oral Surg Oral Med Oral Pathol 1990; 70: 552-4.

39- Hasebe D, Kobayashi T, Hasegawa M, Iwamoto T, Kato K, Izumi N, et al. Changes in oropharyngeal airway and respiratory function during sleep after orthognathic surgery in patients with mandibular prognathism. Int J Oral Maxillofac Surg. 2011;40:584-92.

40- Lee DK, Kim SK. Study on the changes in the upper airway following osteotomy for the mandibular prognathism. TaehanChikkwaUisaHyophoe Chi. 1989; 27(12): 1143-53.

41- Lowe AA, Gionhaku N, Takeuchi K, Fleetham JA. Three-dimensional CT reconstructions of tongue and airway in adult subjects with obstructive sleep apnea. Am J OrthodDentofacialOrthop. 1986; 90: 364-74.

42- Bohlman ME, Hoponik EF, Smith PL, Allen RP, Bleecker ER Goldman SM. CT demonstration of pharyngeal narrowing inadult obstructive sleep apnea. AJR Am J Roentgenol. 1983; 140: 543-8.

43- Galvin JR, Rooholamini SA, Stanford W. Obstructive sleep apnea: diagnosis with ultrafast CT. Radiology. 1989; 171: 775-8.

44- Polo O, Tafti M, Fraga J, Billiard M. Pharyngeal CT studies in patients with mild or severe upper airway obstruction during sleep. Sleep. 1993; 16: 152-5.

45- Rama AN, Tekwani SH, Kushida CA. Sites of obstruction in obstructive sleep apnea. Chest. 2002; 122: 1139-47. 